\title{
Constipation in the population over 50 years of age in Albacete province
}

\author{
M. A. López Cara, P. J. Tárraga López¹, M. Cerdán Oliver², J. M. Ocaña López³, A. Celada Rodríguez', \\ J. Solera Albero ${ }^{3}$ and M. A. Palomino Medina ${ }^{4}$ \\ Primary Health. Center "Casas de Juan Núñez". Albacete. ${ }^{1}$ Health Center $n^{o}$ 6. Albacete. ${ }^{2}$ Health Center Hellin. Albacete. \\ Health Center Alcaraz. Albacete. ${ }^{4}$ Health Center Cardenete. Cuenca, Spain
}

\begin{abstract}
Objective: to determine the incidence of constipation in $\mathrm{Al}$ bacete province and its relation with diet and lifestyle.

Patients and methods: cross-sectional population survey. We studied 414 participants over 50 years of age in Albacete province. 445 persons over 50 years of age were included in the study. All participants were selected by systematic random sampling; 414 participants filled in the questionnaire correctly. Main measures: age, weight and height, marital status, level of education and occupation; presence of a disease, number of sleep hours a day, physical exercise, smoking, alcohol intake, drug intake (anti-inflammatories and laxatives); bowel habit, diet, meal frequency and place; food intake frequency per week, daily intake of water, coffee, tea and herbal beverages; vitamin and fiber supplements; presence of cancer in the family.

Results: $56.9 \%$ of participants were women. Mean age 67.07 years. In Albacete province, $4.4 \%$ of the population over 50 years have a bowel habit consistent with constipation. Most participants had three meals a day (breakfast, lunch, and supper), while 50\% had another meal in the morning or afternoon. These meals took place, habitually, in the domicile. There was a preponderance in daily intake of the following foods: milk (83.7\%), bread (95.1\%), vegetables (68.8\%), fruit (91.8\%), and virgin olive oil (96.6\%). Fish was eaten every one to two days, and pulses and meat every three to six days. $44.4 \%$ of participants drank one to two liters of water a day. Only 3.9\% of participants took some supplement; 35\% of participants were on a diet. It was observed that $97.7 \%$ of participants with more than three defecations a week had a high intake of virgin olive oil; $65.7 \%$ of participants did some physical exercise customarily; $70.2 \%$ of participants were non-smokers, $10.2 \%$ were smokers, and $18.4 \%$ were ex-smokers. With regard to alcohol, the percentage of drinkers was $35.1 \%$. The main class of medications taken by participants was NSAIDs $-14.5 \% ; 79.7 \%$ took neither NSAIDs nor laxatives. Only $2.7 \%$ of participants took laxatives regularly.
\end{abstract}

Recibido: 04-11-05.

Aceptado: 23-01-06.

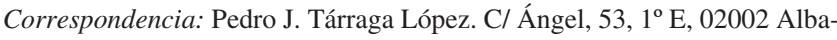
cete. Fax: 967520 526. e-mail: pjtarraga@sescam.jccm.es
Conclusions: Most participants had relatively healthy eating habits.

Key words: Diet. Lifestyle. Bowel habit. Persons.

López Cara MA, Tárraga López PJ, Cerdán Oliver M, Ocaña López JM, Celada Rodríguez A, Solera Albero J, Palomino Medina MA. Constipation in the population over 50 years of age in Albacete province. Rev Esp Enferm Dig 2006; 98: 449-459.

\section{INTRODUCTION}

Constipation is a term that defines a symptom, not a disease or a diagnose, and, as such, indicates a subjective assessment of persons experiencing a defecation disorder. Constipation is characterized not only by its subjective nature but also by its marked complexity, since it can be motivated by many causes and pathogenic/pathophysiological mechanisms, and adopt diverse clinical manifestations (1).

Constipation can be defined by two basic inconveniences (2-4): infrequent defecation and excessive strain. Infrequent defecation is considered when frequency is fewer than three times a week. Strain is deemed excessive when it happens in more than $25 \%$ of defecations. Other inconveniences are: increase in the consistency of feces, reduced fecal mass, feeling of incomplete evacuation, and painful defecation (5-7).

\section{Roma II criteria for the diagnosis of constipation}

At least 12 weeks, which need not be consecutive, in the preceding 12 months of two or more of:

-Strain in $>1 / 4$ defecations. 
-Lumpy or hard stools $>1 / 4$ defecations.

-Sensation of incomplete evacuation $>1 / 4$ defecations.

-Sensation of anorectal obstruction/blockage $>1 / 4$ defecations.

-Manual maneuvers to facilitate $>1 / 4$ defecations (e.g. digital evacuation, support of the pelvic floor); and/or,

$-<3$ defecations per week.

More than seven million persons in Spain are affected by digestive motility disorders. Constipation is among the most frequent problems since it affects $20-25 \%$ of the population, especially women and elderly persons (5).

Approximately two per cent of the population suffers from constipation. The incidence of constipation increases with age, especially in persons over 65 years, when it augments in an exponential way. This disorder is three times more frequent in women than men, although in the elderly its prevalence is very similar in the Caucasian race, developed countries, and lower socioeconomic level $(6,7)$.

Constipation is very frequent among the general population -in our environment the estimate is that self-perceived constipation is close to $25 \%$ in urban areas (8). The annual prevalence of consultation for this reason is approximately $1.2 \%$ of all consultations (men $0.8 \%$; women $1.16 \%$ ) (9). Most patients seek medical advice in family practices (31\%), while $20 \%$ go to an internist, and a scarce $4 \%$ go to a gastroenterologist (10).

Studies that have used questionnaires have detected that self-perceived constipation is reported by $18-21 \%$ of participants (men 8-12\%; women 21-36\%).

On the other hand, questionnaires carried out in the USA have obtained prevalences around $2-3 \%$, with a women/men ratio of 2.5-3/1.

An extensive survey led by the Centre for Constipation Information Duphar (11) and carried out with 15,000 persons in the five more populated countries of Western Europe (Germany, United Kingdom, Italy, France and Spain) revealed that subjective constipation affects $18.40 \%$ of the population (almost 7.5 million persons) in Spain, which places our country in a second position after Italy, with $21.5 \%$ of its population.

Of all the participants who suffered subjective constipation $72 \%$ were women, and $35 \%$ considered that their constipation was chronic, which places Spain at the top of the countries where this survey was carried out. Likewise, Spain is the Western European country where more persons seek medical advice to solve this problem $-25 \%$. These data are consistent with a survey carried out in the Valencian Community, where $22 \%$ of the participants considered themselves constipated. This proportion, though, decreased to $18 \%$ when the definition of constipation was formulated in objective terms (12). Chronic subjective constipation was two times more frequent in women than men, but when using objective criteria the proportion increased threefold. Moreover, when specify- ing obstructive chronic constipation the rate was three and a half times higher in females.

\section{MATERIAL AND METHODS}

Albacete province is one of the five that make up Autonomous Community "Castilla-La Mancha". This regional body is located in the Central Plateau, towards the Southeast of the Iberian Peninsula.

According to the 1996 Census Albacete province had a population of $359,010 \quad(178,130$ men and 180,880 women). A relevant demographic characteristic is its low density of population (24.1 persons $\left./ \mathrm{km}^{2}\right)$, significantly lower than Spain's national mean value (78.4 persons $/ \mathrm{km}^{2}$ ). This fact is consistent throughout CastillaLa Mancha, the third more underpopulated region within the European Union.

The local census of 25 towns and villages randomly selected were used for the study.

All 445 participants, selected by systematic random sampling (statistical power 94.93, alpha 0.05 error), were summoned by means of a personalized letter to fill in a habits and lifestyle questionnaire previously designed and validated. Participants that had passed away or moved were substituted for by the immediately anterior or posterior person in the census. Thus, a total of 445 questionnaires were administered in Albacete province to determine the number of defecations per week in persons over 50 years of age. Once the survey was completed, the statistical analysis related the different variables about diet and lifestyle.

We considered constipated participants those with less than three defecations a week.

Variables included in the questionnaire were:

-Identification of every participant, plus gender, date of birth, age, weight, and height.

- Marital status, education level and occupation.

-Presence of any disease.

- Sleeping hours a day.

-Physical exercise.

- Smoking.

-Alcohol intake.

-Medication use (anti-inflammatories and laxatives).

-Bowel habit.

-Diet.

- Habitual frequency and place of meals.

-Frequency of foods a week.

-Daily intake of water, coffee, tea and other herbal beverages.

- Intake of vitamins and fiber supplements.

-Presence of cancer in the family.

All data were entered in a database (Dbase IV) and analyzed with the statistical package SPSS 10.

After a descriptive analysis of each variable we looked for significant associations between the main variable "bowel habit", expressed as number of defecations per 
week, and the rest of variables. Being "bowel habit" a continuous variable we used mean comparisons when relating with categorical variables, and correlation/regression tools when relating with other continuous variables. Notwithstanding, we did an initial selection of the most important variables in the study.

The categorical variables selected were:

-Presence of a disease.

-Physical exercise.

-Smoking.

-Alcohol intake.

-Medication use.

-Diet.

-Water intake.

-Presence of cancer in the family.

While the continuous variables selected were:

-Age.

—Body mass index (BMI).

\section{RESULTS}

\section{Incidence of constipation in Albacete province}

The mean of defecations per week in people over 50 years of age was 8.15 (SD \pm 3.48 ); $66.7 \%$ of participants defecated seven times a week and $16.6 \% 14$ times a week (Fig. 1). The proportion of participants who were on a diet was $35 \%, 84.7 \%$ of these because of a disease. There was a remarkable age homogeneity among constipated and non-constipated participants $(66.98 \pm 5.84$ years and $66.99 \pm 7.17$ years, respectively).

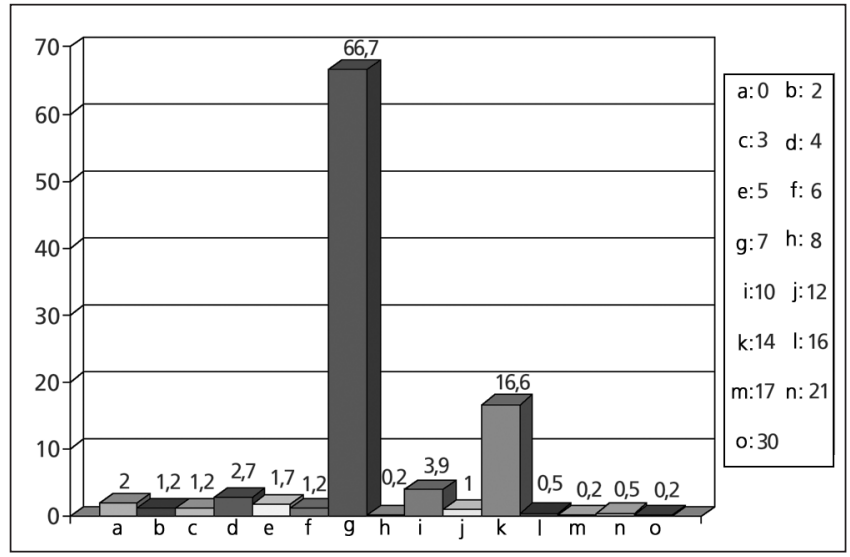

Fig. 1.- Percentages of weekly defecations in the sample. Porcentajes de deposiciones semanales en la muestra.

Although not statistically significant, there is a slight difference in the mean of defecations between the group over 65 years $(8.12)$ and the group at or below 65 years (8.17\%) (Fig. 2).

In Albacete province $4.4 \%$ of the population over 50 have a bowel habit consistent with constipation, which

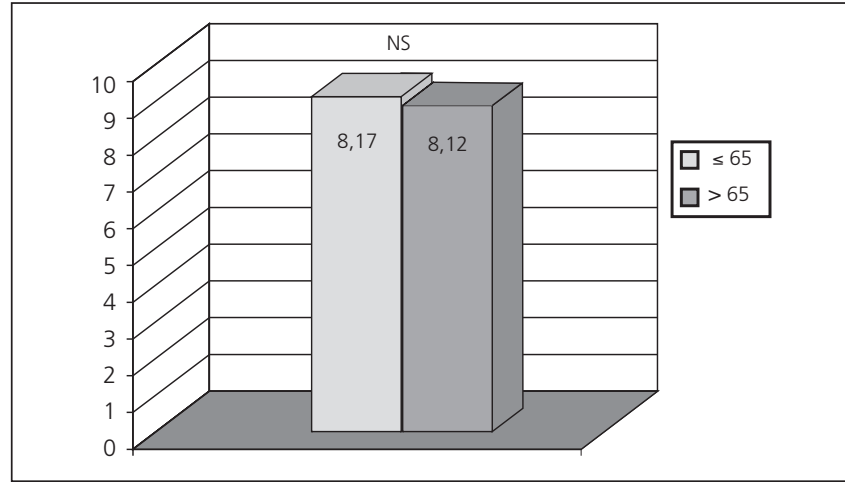

Fig. 2.- Means \pm SD defecations per week per age group. Medias $\pm D E$ de $n^{\circ}$ deposiciones semanales por grupo de edad.

translates as an incidence of 43.47 patients per 100.000 persons per year.

The women:men ratio was 2:1 (Table I).

Of all the participants who reported more than three defecations per week $97.7 \%$ had a high intake of virgin olive oil, versus $88.9 \%$ of participants with three or less defecations per week who also reported a high intake of virgin olive oil. This difference established a statistically significant relation between both variables (Chi-square $=$ 5.083, 1 d.o.f, $\mathrm{p}=0.004$ ) (Table II).

Table I. Gender frequency per number of defecations per week

\begin{tabular}{|c|c|c|c|c|c|}
\hline & & & \multicolumn{2}{|c|}{ Defecations } & \multirow{2}{*}{ Total } \\
\hline & & & $\begin{array}{l}\leq 3 \text { defecations } \\
\text { per week }\end{array}$ & $\begin{array}{l}>3 \text { defecations } \\
\text { per week }\end{array}$ & \\
\hline \multirow[t]{6}{*}{ Gender } & Men & Number & 5 & 169 & 174 \\
\hline & & $\%$ gender & $2.9 \%$ & $97.1 \%$ & $100.0 \%$ \\
\hline & & $\%$ of defectations & $27.8 \%$ & $43.3 \%$ & $42.6 \%$ \\
\hline & Women & Number & 13 & 221 & 234 \\
\hline & & $\%$ gender & $5.6 \%$ & $94.4 \%$ & $100.0 \%$ \\
\hline & & $\%$ of defectations & $72.2 \%$ & $56.7 \%$ & $57.4 \%$ \\
\hline \multirow[t]{3}{*}{ Total } & & Number & 18 & 390 & 408 \\
\hline & & $\%$ gender & $4.4 \%$ & $95.6 \%$ & $100.0 \%$ \\
\hline & & $\%$ of defectations & $100.0 \%$ & $100.0 \%$ & $100.0 \%$ \\
\hline
\end{tabular}

\section{Bivariate relations with the main variable: bowel habits}

The mean of defecations in the subgroup with no disease was $8.26 \pm 2.82$ times/week, while the subgroup with a disease had a mean of $8.12 \pm 3.65$ time/week. We performed Student's t-test for independent groups but the result was not significant $(\mathrm{t}=0.348,407$ d.o.f., $\mathrm{p}=0.728)$ (Fig. 3).

Although Student's t-test did not find statistically significant differences $(t=-0.831,405$ d.o.f., $p=0.407)$ the subgroup that habitually took physical exercise had a number of defecations per week (8.25) higher than those who did not (7.95\%) (Fig. 4). 
Table II. Frequency of virgin olive oil intake

\begin{tabular}{|c|c|c|c|c|c|}
\hline & \multicolumn{2}{|c|}{ Defecations } & \multirow[t]{2}{*}{ Total } \\
\hline & & & $\begin{array}{l}\leq 3 \text { defecations } \\
\text { per week }\end{array}$ & $\begin{array}{l}>3 \text { defecations } \\
\text { per week }\end{array}$ & \\
\hline \multirow[t]{4}{*}{$\begin{array}{l}\text { Virgin } \\
\text { olive oil } \\
\text { intake }\end{array}$} & $\begin{array}{l}\text { Low } \\
\text { intake }\end{array}$ & $\begin{array}{l}\text { Number } \\
\% \text { of virgin olive } \\
\text { Oil intake }\end{array}$ & $\begin{array}{l}2 \\
18.2 \%\end{array}$ & $\begin{array}{l}9 \\
81.8 \%\end{array}$ & $\begin{array}{l}11 \\
100.0 \%\end{array}$ \\
\hline & & $\%$ of defecations & $11.1 \%$ & $2.3 \%$ & $2.7 \%$ \\
\hline & $\begin{array}{l}\text { High } \\
\text { intake }\end{array}$ & $\begin{array}{l}\text { Number } \\
\% \text { of virgin olive } \\
\text { Oil intake }\end{array}$ & $\begin{array}{l}16 \\
4.0 \%\end{array}$ & $\begin{array}{l}381 \\
96.0 \%\end{array}$ & $\begin{array}{l}397 \\
100.0 \%\end{array}$ \\
\hline & & $\%$ of defecations & $88.9 \%$ & $97.7 \%$ & $97.3 \%$ \\
\hline \multirow[t]{2}{*}{ Total } & & $\begin{array}{l}\text { Number } \\
\% \text { of virgin olive } \\
\text { Oil intake }\end{array}$ & $\begin{array}{l}18 \\
4.4 \%\end{array}$ & $\begin{array}{l}390 \\
95.6 \%\end{array}$ & $\begin{array}{l}408 \\
100.0 \%\end{array}$ \\
\hline & & $\%$ of defecations & $100.0 \%$ & $100.0 \%$ & $100.0 \%$ \\
\hline
\end{tabular}

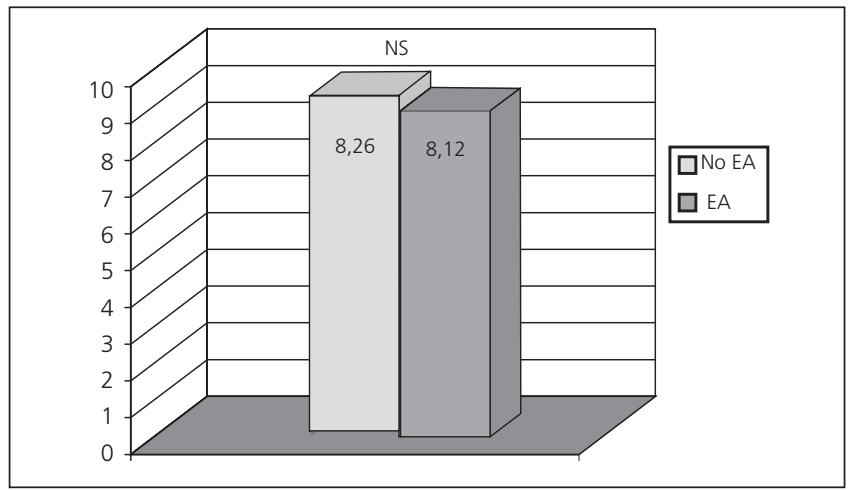

Fig. 3.- Means \pm SD number of defecations per week according to variable presence of a disease.

Medias $\pm D E$ del $n^{\circ}$ de deposiciones semanales según la variable "enfermedades anteriores" de los encuestados.

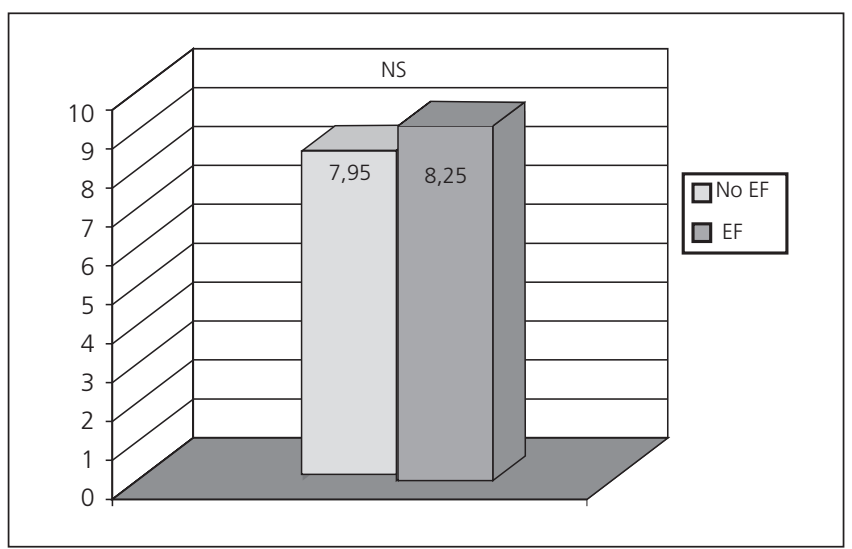

Fig. 4.- Means \pm SD number of defecations per week according to variable presence of physical exercise.

Medias $\pm D E$ del $n^{\circ}$ de deposiciones semanales según la variable "ejercicio físico" de los encuestados.

With regard to smoking, the categorical variable "breaks" the continuous variable in four subgroups, from "non-smoker" to "ex-smoker". This fact leads to high data dispersal, producing subgroups like "occasional smoker" with only five participants. Therefore we had to use non-parametric statistics for mean comparisons in these four subgroups. The subgroup with a higher mean in number of defecations per week was "non-smokers" (8.28), but the difference was non-significant according to the non-parametric Kruskal-Wallis test (Chi-square = 1.992, 3 d.o.f., $\mathrm{p}=0.574$ ) (Fig. 5).

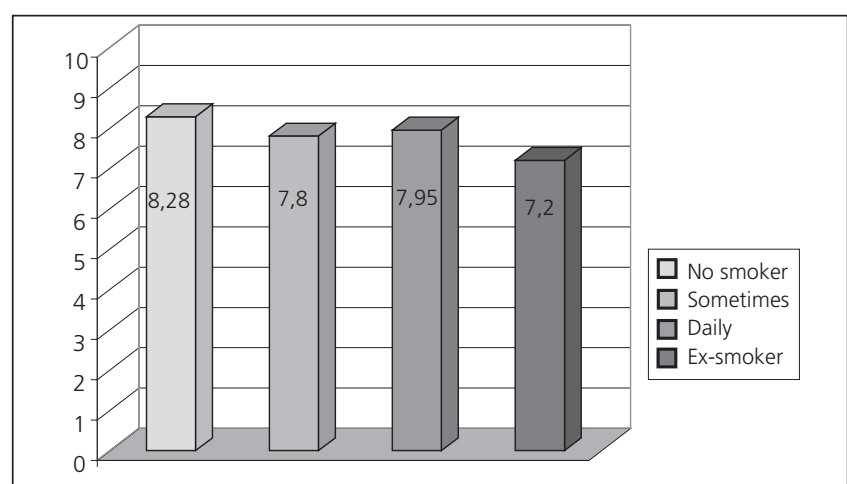

Fig. 5.- Means \pm SD number of defecations per week according to variable "smoking".

Medias $\pm D E$ del $n^{\circ}$ de deposiciones semanales según la variable "tabaquismo" de los encuestados.

The ingestion of a toxic substance causes again a fewer number of defecations per week. The mean in the alcohol consumption subgroup is 7.47 while in the subgroup with no consumption is 8.26. However, Student-t test for independent groups did not show significant differences $(\mathrm{t}=0.896,352.790$ d.o.f., $\mathrm{p}=0.406)$ (Fig. 6).

Participants who did not take any medicines had a mean (8.45) higher than the rest. The group who took laxatives as well as NSAIDs had the lowest mean (5). Comparisons between the subgroup who did not take any medications and the subgroups who took only laxatives or laxatives plus NSAIDs resulted in significant differences (Fig. 7).

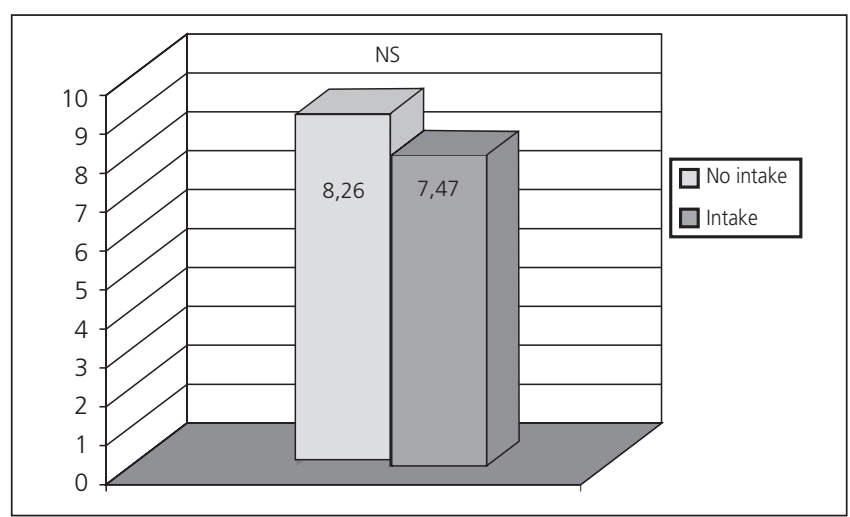

Fig. 6.- Means \pm SD number of defecations per week according to variable alcohol intake.

Medias $\pm D E$ del $n^{\circ}$ de deposiciones semanales según la variable "consumo de alcohol" de los encuestados. 


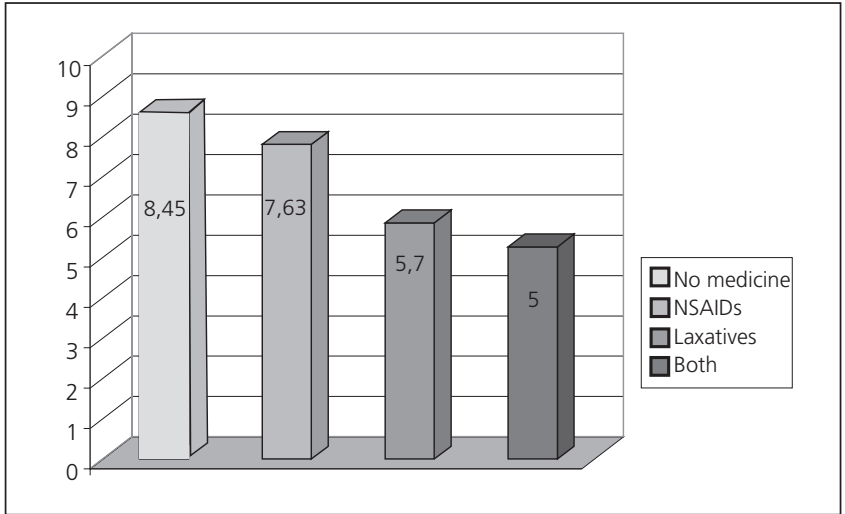

Fig. 7.- Means \pm SD number of defecations per week according to variable medicines intake $\left(^{*}\right)$ no intake versus laxatives and both. Medias $\pm D E$ del $n^{\circ}$ de deposiciones semanales según la variable "consumo de medicamentos" de los encuestados. (*): sig vs. laxantes y ambos.

The subgroup that followed some kind of diet had a higher mean (8.44) versus those who did not (8). Notwithstanding, Student's t-test for independent groups yielded no significant difference $(\mathrm{t}=-1.231,407$ d.o.f., $\mathrm{p}$ $=0.219)$ (Fig. 8).

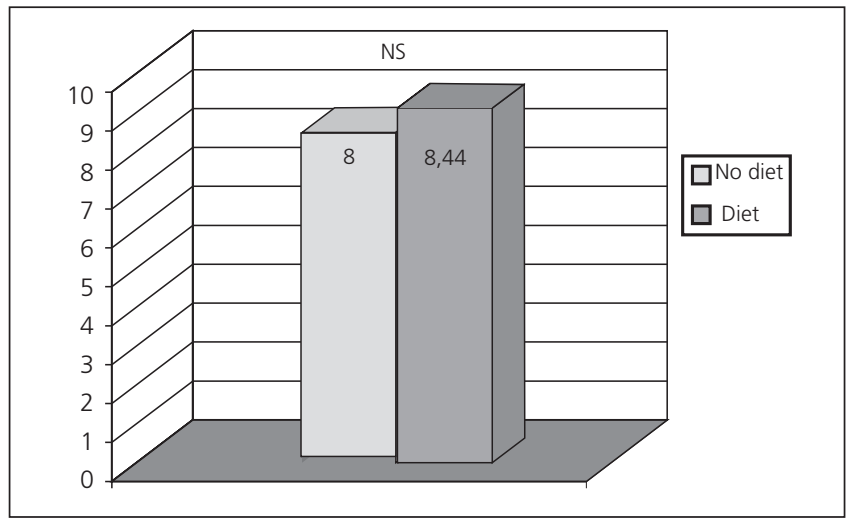

Fig. 8.- Mean \pm SD number of defecations per week according to variable diet.

Media $\pm D E$ del $n^{\circ}$ de deposiciones semanales según la variable "realizar dieta o régimen" de los encuestados.

We could see an increase in the mean of defecations per week in the group with moderate water intake (1-2 litres) when compared to the other two groups. According to the one-way ANOVA test, differences between means were not significant $(\mathrm{F}=0.450, \mathrm{p}=0.638)$ (Fig. 9).

The subgroup without cancer in the family had a higher mean (8.37), but Student's t-test showed no significant difference ( $\mathrm{t}=1.426,407$ d.o.f., $\mathrm{p}=0.155)$ (Fig. 10).

Persons over 50 years of age in Albacete province have a high intake of milk, white bread, vegetables, fruits, and virgin olive oil (Table III).

The only significant comparisons were for virgin olive oil $(p=0.004)$ and meat $(p=0.011)$. In the case of fruits,

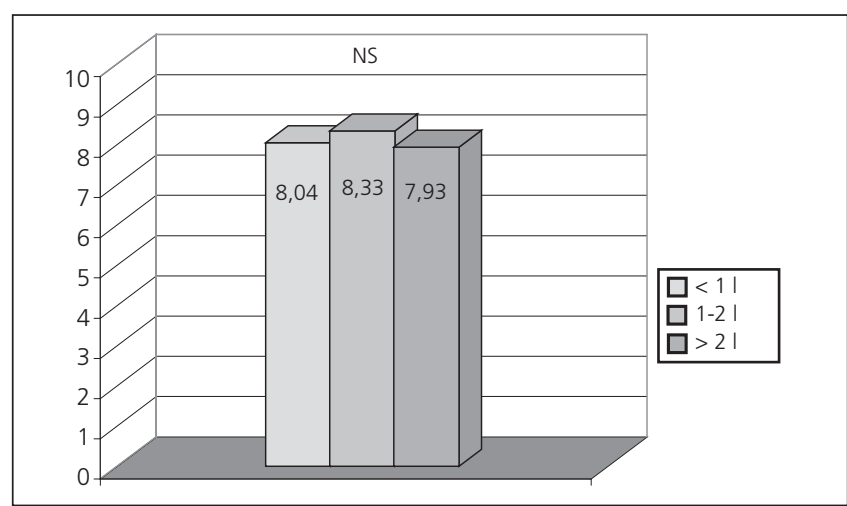

Fig. 9.- Means \pm SD number of defecations per week according to variable water intake.

Medias $\pm D E$ del $n^{\circ}$ de deposiciones semanales según la variable "consumo de agua" de los encuestados.

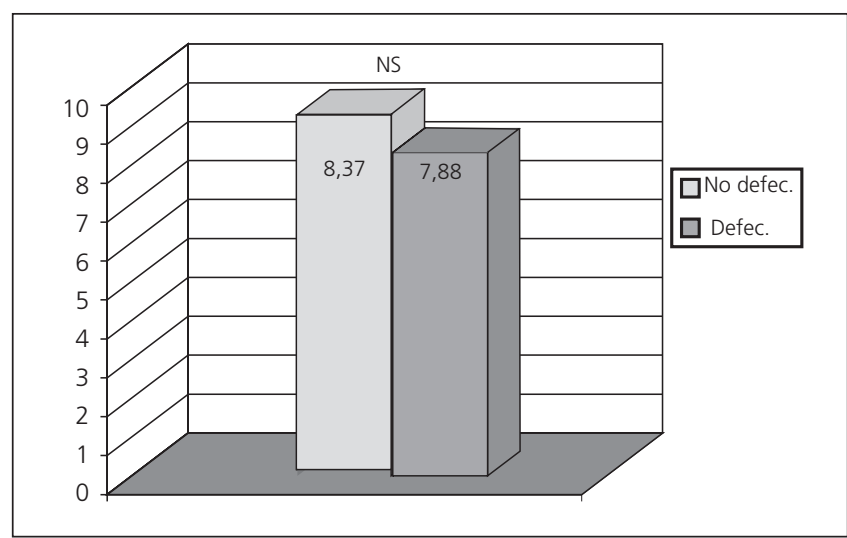

Fig. 10.- Means \pm SD number of defecations per week according to variable presence of cancer in family.

Medias $\pm D E$ del $n^{\circ}$ de deposiciones semanales según la variable "antecedentes familiares de cáncer" de los encuestados.

results were very close to the confidence level $(p=0.063)$ (Table IV).

To sum it up, with a confidence level of at least $95 \%$, participants who more frequently ate fruits, virgin olive oil or meat had a higher mean of defecations per week when compared to the rest of participants, with a significant difference.

\section{DISCUSSION}

Elderly persons have a five times higher probability of suffering constipation when compared to younger persons. In most cases, reasons include diets, lack of physical exercise, use of medicines, and poor bowel habits.

In our study the percentage of constipation in Albacete province for persons over 50 years of age was $4.4 \%$, lower than the Spanish mean value $(18.4 \%$ according to Duphar's Center for Constipation Information) (13). 
Table III. Frequency of food intakes in two categories

\begin{tabular}{lcc}
\hline Food & $\begin{array}{c}\text { Low intake } \\
\%\end{array}$ & $\begin{array}{c}\text { High intake } \\
\%\end{array}$ \\
\hline Milk & 10.9 & 89.1 \\
White bread & 3.4 & 96.6 \\
Wholemeal bread & 94.4 & 5.6 \\
Buns, pastries & 61.7 & 38.3 \\
Biscuits & 59.5 & 40.5 \\
Pasta, rice & 78.3 & 21.7 \\
Eggs, omelette & 83.3 & 16.7 \\
White fish & 82.9 & 17.1 \\
Blue fish & 89.6 & 10.4 \\
Pulses & 68.1 & 31.9 \\
Vegetables & 12.6 & 87.4 \\
Fruits & 4.1 & 95.9 \\
Virgin olive oil & 2.7 & 97.3 \\
Butter & 98.7 & 1.3 \\
Cold meat and sausages & 77.0 & 23.0 \\
Meat & 36.5 & 63.5 \\
\hline
\end{tabular}

Table IV. Means \pm SD subgroups of foods intake/number of defecations per week

\begin{tabular}{lccc}
\hline & Low intake & High intake & $\begin{array}{c}\text { Means } \\
\text { comparisons }\end{array}$ \\
\hline Food & Mean \pm SD & Mean \pm SD & Significant \\
\hline Milk & $7.89 \pm 2.90$ & $8.19 \pm 3.55$ & NS \\
White bread & $7.79 \pm 4.06$ & $8.17 \pm 3.47$ & NS \\
Wholemeal bread & $8.21 \pm 3.54$ & $7.95 \pm 3.35$ & NS \\
Buns, pastries & $8.21 \pm 3.42$ & $8.04 \pm 3.62$ & NS \\
Biscuits & $8.03 \pm 3.29$ & $8.46 \pm 3.82$ & NS \\
Pasta, rice & $8.15 \pm 3.52$ & $8.15 \pm 3.35$ & NS \\
Eggs, omelette & $8.10 \pm 3.54$ & $8.54 \pm 3.35$ & NS \\
White fish & $8.24 \pm 3.52$ & $7.75 \pm 3.31$ & NS \\
Blue fish & $8.21 \pm 3.57$ & $7.67 \pm 2.87$ & NS \\
Pulses & $8.23 \pm 3.54$ & $7.98 \pm 3.36$ & NS \\
Vegetables & $8.42 \pm 3.29$ & $8.12 \pm 3.52$ & NS \\
Fruits & $6.63 \pm 2.78$ & $8.22 \pm 3.50$ & $0.063^{* *}$ \\
Virgin olive oil & $5.73 \pm 1.90$ & $8.22 \pm 3.50$ & $0.004^{* *}$ \\
Butter & $8.20 \pm 3.53$ & $7.40 \pm 4.28$ & NS \\
Cold meat and sausages & $8.13 \pm 3.48$ & $8.19 \pm 3.48$ & NS \\
Meat & $7.57 \pm 3.63$ & $8.49 \pm 3.35$ & 0.011 \\
\hline
\end{tabular}

*: statistic $Z_{;} * *:$ Mann-Whitney test.

Regarding gender, the proportion is 2.5 constipated women per each man, which is consistent with other studies, while on the subject of age results were very homogeneous $(66.98 \pm 5.84$ years and $66.99 \pm 7.17$ years, respectively). Mean defecations were slightly lower (8.12) in the group aged over 65.

Persons over 50 years of age in Albacete province have a healthy lifestyle.

The percentage of persons who eat bread or cereals $(96.6 \%)$, vegetables $(87.4 \%)$ and fruits $(95.9 \%)$ is higher than the percentage of persons meeting the recommended allowances for these foods in Spain (bread: $82 \%$, vegetables: $69 \%$, fruits: $64 \%$, according to the Health National Survey 2001) (14).
Participants who ate fruits, virgin olive oil, or meat more frequently significantly increased their mean of defecations per week.

These findings confirm existing studies that recommend a varied and balanced diet with a high intake of fruits for their high fiber contents, and virgin olive oil for its lubricant effect, which improves bowel movement and decreases constipation.

Number of defecations is higher in persons who do physical exercise than in persons who do not. This is also in agreement with most studies (15-18) in which physical exercise is recommended because it shortens gastrointestinal transit. According to Meshkimpour (19-21) physical exercise does not have an important role in the treatment of constipation but increases colon motility in active persons. The effects of physical exercise are controversial, since most authors have not been able to demonstrate that it increases the frequency or volume of defecations (21).

With regard to smoking in our study, the subgroup of non-smokers had a higher number of defecations per week. This is in disagreement with many studies on smoking effects -it seems that smoking, in increasing intestinal motility, should increase the number of defecations (Medline Plus: use of smoking and spit tobacco 2002). However, in our study, participants who did smoke daily had a higher number of defecations per week than ex-smokers.

We have observed that, due to its effect on intestinal motility, persons who habitually have alcohol have a fewer number of defecations per week than persons who do not.

With regard to use of medications we could observe that participants who did not take any kind of medication had a higher mean of defecations per week versus the rest. On the contrary, those who took laxatives or NSAIDs had a lower mean when compared to the rest of participants (20-23).

Comparisons between the group taking no medications and the group using laxatives or laxatives plus NSAIDs were significant. However, the group without medication did not significantly differ from the group with NSAIDs.

All this is in agreement with the fact that, on occasion, constipation is secondary to medications and laxative abuse.

\section{REFERENCES}

1. Herrerías Gutiérrez JM, Amador Romero FJ. Gastroenterología y Hepatología en Atención Primaria. Madrid: Ediciones Aula Médica, S.L.; 2002. p. 187-95.

2. Leonnard-Jones JE. Constipation. In: Feldman M, Scharschmidt BF, Sleisenger MH, editors. Sleisenger and Fordtran's gastrointestinal and liver disease. Pathophysiology, diagnosis, management. $6^{\text {th }}$ ed. Philadelphia: W.B. Saunders Company; 1998. p. 174-9.

3. Husui-Ali R, Gómez Rodríguez BJ, Mendoza Olivares FJ, García Montes JM, Sánchez-Gey Venegas S, Herrerías Gutiérrez JM. Medida del tiempo de tránsito colónico en el estreñimiento crónico idiopático. Rev Esp Enferm Dig 2003; 95: 181-5. 
4. Benages A. Valoración del tiempo de transito colónico en los pacientes con estreñimiento crónico idiopático. Rev Esp Enferm Dig 2003; 95: 171-5.

5. Moreno-Osset E, Ballester Fayos J, Añón Rodríguez R. Estreñimiento. In: Vilardell F, Rodés J, Malagelada JR, Pajares JM, Pérez Mota A, Moreno González E, Puig la Calle J, editores. Enfermedades Digestivas. Madrid: Grupo Aula Médica S.A.; 1998. p. 883-96.

6. Wald A. Approach to the patient with constipation. In: Yamada T, Alpers DH, Laine L, Owyang C, Powell DW, editors. Textbook of gastroenterology. $3^{\text {rd }}$ ed. Filadelfia: Lippincott Williams and Wilkins; 1999. p. $910-26$

7. Moreno-Osset E, Ballester Fayos J, Antón Conejero MD. Manometría colónica. In: Vilardell F, Rodés J, Malagelada JR, Pajares JM, Pérez Mota A, Moreno González E, Puig la Calle J, editores. Enfermedades Digestivas. Madrid: Grupo Aula Médica S.A.; 1998. p. 871-82

8. Read NW, Timms JM. Defecation and the pathophysiology of constipation. Clin Gastroenterol 1986; 15: 937-65.

9. Cummings $\mathrm{JH}$. Constipation, dietary fibre and the control of large bowel function. Postgrad Med J 1984; 60: 811-9.

10. Calvo Boigues B. Hábito intestinal y epidemiología de los trastornos funcionales intestinales. Estudio poblacional [dissertation]. Valencia: Universitat de Valencia; 1994.

11. Sonnenberg A, Koch TR. Physicians visits in the United Status for constipation: 1958-1986. Dig Dis Sci 1989; 34: 606-11.

12. Moreno-Osset E, Ballester Fayos J, Añón Rodríguez R. Estreñimiento crónico idiopático. Rev And Pat Digest 1996; 19: 249-57.

13. Bixquert M. Estreñimiento del adulto. In: Bixquert M, López C, Sas- tre A y Serrano P, editores. La consulta diaria en el estreñimiento crónico. Madrid: Masson; 2000. p. 23-49.

14. Gálvez C, Garrigues V, Ortiz V, Ponce J. Estreñimiento crónico (EC). Un estudio de prevalencia en la población general. Rev Sdad Valenciana Patol Dig 1999; 18: 125-6.

15. Devroede G. Constipation. In: Kumar D, Wingate D, editors. An illustrated guide to Gastrointestinal motility. $2^{\text {nd }}$ ed. Edimburgo: Churchill Livingstone; 1993. p. 595-654

16. Ministerio de Sanidad y Consumo. Encuesta Nacional de Salud de 1987, 1993, 1997 y 2001. Madrid.

17. Martín Zurro A, Gil Canalda I. Claves Clínicas en Medicina de Familia. Aparato digestivo. Barcelona: Editorial Masson, S.A.; 2000. p. 56-7.

18. Harrinson RL, Leeds AR, Bolster NR, Judd PA. Exercise and wheat bran; effect on whole gut transit. Proc Nutr Soc 1980; 39: 22-3.

19. Cordain L, Latin RW, Behnke JJ. The effects of an aerobic running program on bowel transit time. J Sports Med 1986; 26: 101-4.

20. Holdstock DJ, Misiewicz JJ, Smith T, Rowlands E. Propulsion (mass movement) in the human colon and its relationship to meals and somatic activity. Gut 1970; 11: 91-9.

21. Meshkinpour H, Kemp C, Fairshter R. Effects of aerobics exercise on mouth-to-cecum transit time. Gastroenterology 1989; 96: 938-41.

22. Robertson G, Meshkinpour H, Vandenberg K, Cohen A, Wilson A Effects of exercise on total and segmental colon transit. J Clin Gastroenterol 1993; 16: 300-3

23. Meshkinpour H, Selod S, Movahedi H, Nami N, James N, Wilson A. Effects of regular exercise in management of chronic idiopathic constipation. Dig Dis Scie 1998; 43: 2379-83. 